J. Reprod. Fert. (1970) 23, 181-184

\title{
THE BINDING OF OUABAIN TO SPERMATOZOA OF BOAR AND RAM
}

\author{
J. M. O'DONNELL ANd J. G. ELLORY \\ A.R.C. Institute of Animal Physiology, Babraham, Cambridge
}

(Received 1st May 1970)

Measurements of the alkali cation content of spermatozoa from several mammals (Quinn \& White, 1967, 1968a; O'Donnell, 1969) suggested that these cells may possess active transport systems for sodium and potassium, and an ATPase with the properties of an alkali cation-transport system has been demonstrated in the spermatozoa of bull, boar and ram (Quinn \& White, 1968b) located mainly in the mid-piece. The cardiac glycosides, ouabain and digoxin, which specifically bind to ATPase sites on the membranes of a variety of mammalian cells (Matsui \& Schwartz, 1968; Ellory \& Keynes, 1969; Baker \& Willis, 1969), have been shown to bind to the cell membrane of the mid-piece-tail region in bull spermatozoa (O'Donnell \& Ellory, 1970). Although the binding occurred at a membrane site in proximity to a source of metabolic energy and was sensitive to metabolic inhibition, the binding reaction was not affected by the external potassium concentration, in contrast to other cells so far investigated. It is possible that the lack of sensitivity of spermatozoa to potassium in this respect is related to the existence of an unusually high potassium concentration in the natural environments of these cells. Because of the known differences in metabolic pattern between species of spermatozoa (Mann, 1964), the ouabainbinding capacity of spermatozoa of boar and ram has been investigated.

The technique of measurement of glycoside binding, using tritiated ouabain (New England Nuclear Corp.) followed that described for bull spermatozoa by O'Donnell \& Ellory (1970). Ram semen was obtained as first ejaculates and the spermatozoa washed and resuspended in artificial seminal plasma by gentle centrifugation. The sperm-rich fraction of boar ejaculate was collected directly into a $\mathrm{CO}_{2}$-saturated diluent (Graves \& Salisbury, 1959) in a Thermos flask. Spermatozoa, immobilized by the $\mathrm{CO}_{2}$ of the diluent, were washed and resuspended in artificial seminal plasma. Control suspensions of both ram and boar spermatozoa, at the start of the incubation with labelled glycoside, showed that at least $50 \%$ of the cells were progressively motile and were predominantly but not exclusively unaggregated.

The motility of spermatozoa in all preparations was assessed before and after the $30-\mathrm{min}$ incubation at $37^{\circ} \mathrm{C}$ in the ouabain-containing medium. Control preparations showed no significant diminution in motility compared with cells incubated in ouabain-free medium, indicating that the ouabain concentration employed to measure glycoside binding, i.e. $5 \times 10^{-7} \mathrm{M}$, had no 
inhibitory action on motility. The effects of added metabolic inhibitors were scored on an arbitrary scale.

From the activity found in washed cell suspensions after incubation with labelled ouabain, the number of molecules of ouabain bound per cell could be calculated. The summarized data from these experiments are presented in Table 1. Each figure is the mean of at least six replicates. Since there was some variation between ejaculates, the effects of each treatment were assessed by comparison with a control preparation of cells from the same ejaculate. The

\section{TABLE 1}

EFFECTS OF METABOLIG INHIBITORS AND DETERGENT TREATMENT ON NUMBERS $\left(\times 10^{3}\right)$ OF MOLEGULES OF OUABAIN BOUND IN BOAR AND RAM SPERMATOZOA

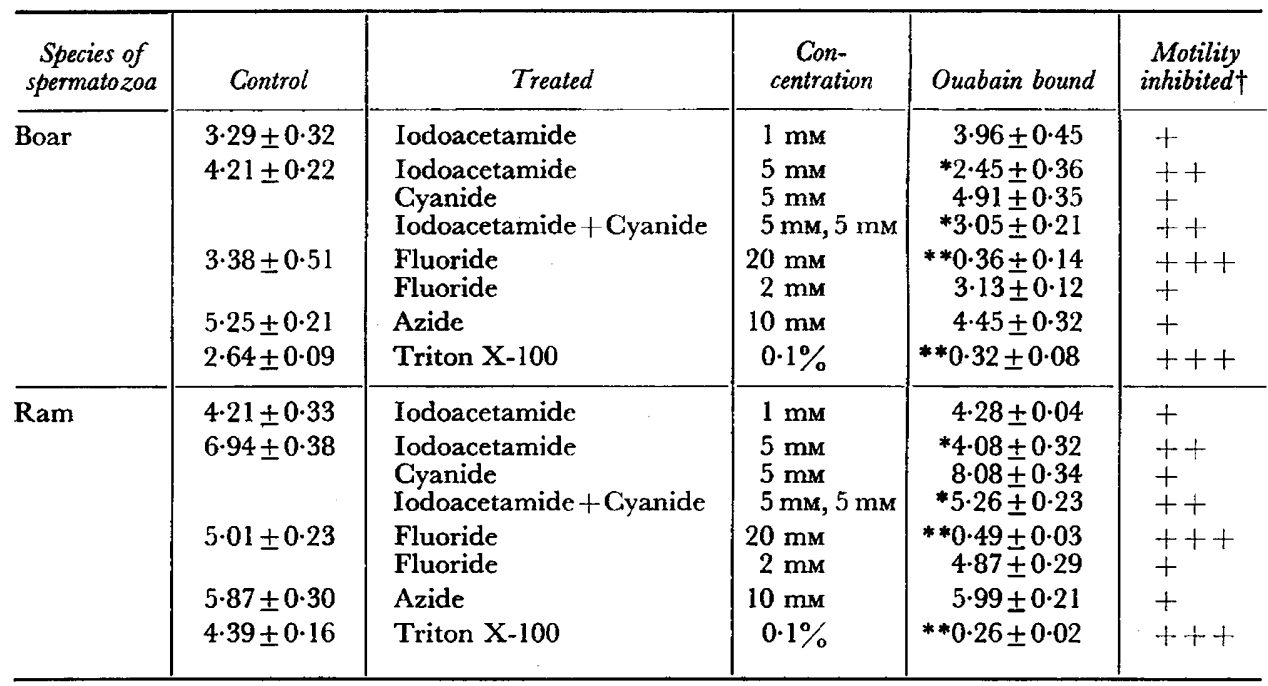

$* P<0.05, * * P<0.01$, Significantly different from control.

$\dagger$ Inhibitor arbitrarily scored in comparison with control: +++ complete; ++ intermediate; + slight or zero.

variation between controls prepared from different ejaculates may be ascribed to normal variance in semen quality.

The control preparations of both boar and ram spermatozoa gave values for the number of ouabain molecules bound per cell which were very similar to the corresponding number for bull spermatozoa. Likewise, treatment of both types of cell with the detergent, Triton X-100, greatly reduced the extent of binding (Table 1 ). This is to be expected since the detergent treatment may be assumed to solubilize the cell membranes in the case of all three kinds of spermatozoa, and binding sites for ouabain have been found to be localized mainly in the membranes of mid-piece and tail. Detergent treatment fully inhibited motility.

For ouabain to bind to the transport ATPase complex, the most favourable conditions are provided by the presence of suitable concentrations of $\mathrm{Mg}^{++}$, $\mathrm{Na}^{+}$and ATP, although studies in vitro with ATPase preparations have shown that other nucleotide triphosphates and certain diphosphates can substitute 
for ATP (Matsui \& Schwartz, 1968). When studying the binding reaction in intact cell preparations, metabolic inhibitors may be used to lower the intracellular ATP level and thus reduce the binding. This technique has been successfully applied to a variety of cells in culture (Baker \& Willis, 1969).

In addition to detergent treatment, four metabolic inhibitors were employed in investigating the relation between ouabain binding and metabolism (Table 1). Means were also sought to distinguish between general effects of inhibitors of metabolism operating by a reduction in generation of ATP, and effects at the cell membrane, such as precipitation of $\mathrm{Ca}^{++}$or $\mathrm{Mg}^{++}$, which would also inhibit the reaction. As in bull spermatozoa, $20 \mathrm{~mm}-\mathrm{NaF}$ had a very marked inhibitory effect on binding; $2 \mathrm{~mm}-\mathrm{NaF}$, however, had no significant effect on either cell, and it is likely that fluoride inhibition was brought about by a direct effect on the membrane. At $20 \mathrm{~mm}$ concentrations, $\mathrm{NaF}$ caused complete cessation of motility. Iodoacetamide, which was inhibitory for bull spermatozoa at $1 \mathrm{~mm}$ concentrations, had a significant effect on ram and boar spermatozoa at $5 \mathrm{~mm}$, but not at $1 \mathrm{~mm}$ concentrations. This compound has been shown to depress glycolysis without affecting the cation transport system in human red cells (Garrahan \& Glynn, 1967) and its effect on spermatozoa at this concentration may be assumed to be primarily an inhibition of fructolysis.

Both cyanide and azide were without inhibitory effect on ouabain binding in these cells. Again, this is in contrast to bull spermatozoa in which the reaction is cyanide-sensitive. This insensitivity to cyanide is unexpected, particularly in boar spermatozoa which are less efficient 'anaerobes' than bull or ram spermatozoa (Mann, 1964). In the presence of an inhibitory concentration of iodoacetamide, cyanide showed the same slight stimulatory effect as when used alone.

These results show that spermatozoa of ram and boar, like those of bull, can bind ouabain under favourable metabolic conditions and that the binding takes place in a membrane region that is removable by detergent treatment. Interpretation of this binding capacity is complicated in the case of spermatozoa on account of, first, the known ability of these cells to bind a variety of very different compounds. Second, although the binding reaction was sensitive to metabolic inhibitors, the expected differences in sensitivity due to metabolic pattern were not seen in boar as they were in bull and ram spermatozoa. There was a correlation between inhibition of binding and inhibition of motility, but although the binding was specific in spermatozoa of boar and ram it cannot unequivocally be interpreted as being related to cation transport sites.

Boar semen was obtained through the courtesy of Dr G. Polge and Mr I. Wilmut of the Animal Research Station, Huntingdon Road, Cambridge.

\section{REFERENCES}

BAKER, P. F. \& Willis, J. S. (1969) On the number of sodium pumping sites in cell membranes. Biochim. biophys. Acta, 183, 646.

ElLory, J. C. \& Keynes, R. D. (1969) The binding of tritiated digoxin to human red cell ghosts. Nature, Lond. 221, 776. 
Garrahan, P. J. \& Glynn, I. M. (1967) The incorporation of inorganic phosphate into adenosine triphosphate by reversal of the sodium pump. F. Physiol., Lond. 192, 237.

Graves, G. N. \& Salisbury, G. W. (1959) The preparation of epididymal-like ejaculated bovine spermatozoa. F. Dairy Sci. 43, 932.

ManN, T. (1964) The biochemistry of semen and the male reproductive tract, 2nd edn. Methuen, London.

Matsur, H. \& Schwartz, A. (1968) Mechanism of cardiac glycoside inhibition of $\left(\mathrm{Na}^{+}-\mathrm{K}^{+}\right)$dependent ATPase from cardiac tissue. Biochim. biophys. Acta, 151, 655.

O'DoNNELL, J. M. (1969) Intracellular levels of sodium and potassium in bull spermatozoa in relation to cell metabolism. F. Reprod. Fert. 19, 207.

O'DonNeli, J. M. \& ELLORY, J. C. (1970) The binding of cardiac glycosides to bull spermatozoa. Experientia, 26, 20.

Quins, P. J. \& WhITE, I. G. (1967) Active cation transport in dog spermatozoa. Biochem. F. 104, 328.

Quinn, P. J. \& White, I. G. (1968a) The transport of cations by ram and bull spermatozoa. Aust. J. biol. Sci. 21, 781.

QuinN, P. J. \& WhITE, I. G. (1968b) Distribution of adenosinetriphosphatase activity in ram and bull spermatozoa. F. Reprod. Fert. 15, 449. 